\title{
The Application of the Theory of Project Teaching Method in College English Teaching
}

\author{
Jing DING
}

Foreign Languages Department, Dalian Jiaotong University, China

\begin{abstract}
With the globalization of social economy, the common language is particularly important in the foreign trade exchanges, and English education is widely spread in our country. As a language subject, English teaching for practical purpose and the cultivation of application ability have high requirements. In recent years, with the education curriculum reform in our country, the project teaching method is applied to each specialty of the institutions teaching. Also, this method is also used in college English classroom, effectively strengthen the English practice. This paper expounds the meaning of project teaching method and its theoretical basis, analyzes the significance of the implementation of project teaching, and discusses the application of project teaching method in college English teaching and the matters needing attention.
\end{abstract}

KEYWORD: Project teaching method; College English; The theory basis; Important meaning; Application

\section{THE MEANING OF PROJECT TEACHING METHOD AND THEORY BASIS}

Project teaching method is a kind of teaching methods that make students as the center of the classroom, this method and can be called crossprofessional courses. This method of teaching is to put the student under the guidance of the teacher and let them finish the teacher assigned task which is in the form of "project". Teacher set project includes many aspects of knowledge, varying from the project research, analysis, information data collection, project design, project specific implementation to the final evaluation that requires the achievement of students on the basis of combining the teacher guidance and independent learning. Students in the process of project completion need real mind, every link of the whole process of the project and in-depth understanding. At the same time, independent learning arouses the interest in learning and leads to more profound mastery of the knowledge of all the content within the teaching plan.

Project teaching method originated in Europe on labor education ideas, merged the concepts of education in other countries, after continuous reform and development and become an important theoretical idea and teaching method. Project teaching mode is based on modern education, thought social culture and the unity of modern productive forces and production relations as the development goals, to make teaching more practical.
This is a change of learning style. And it is the active exploration of the students' autonomous learning and the cultivation of independent thinking and problem solving ability. Traditional way of learning is that the students passively accept imparting knowledge from teachers, and the project teaching method is to let students stand on the main body status and carry on the investigative study. Then teachers carry out a project layout and play the role of a project director of students and also the role of the supervisor to make sure the completion of the project for students to obtain the multiple sources of knowledge and to apply knowledge in the practice of the opportunity of comprehensive ability.

\section{THE IMPLEMENTATION OF PROJECT TEACHING IN COLLEGE ENGLISH TEACHING}

The biggest difference between the project teaching method and traditional teaching method is that the role of students and teachers in the teaching position changed. Compared with traditional cramming teaching, project teaching method puts more emphasis on the importance of students in learning. Teaching purpose is to let students grasp the knowledge and highlighting the subjective initiative of students has become the first task of teaching. In the initial stage, the project teaching method is widely used in higher vocational and technical 
education and it promotes the international education in the education industry.[2] In recent years, many colleges and universities start the project teaching method and has made great teaching achievements. Based on college English course as an example, this paper from the following aspects of the significance of project teaching method is analyzed.

\subsection{Arousing students' interest in learning}

After entering the university, the great changes of the way of learning have taken place in comparison with secondary school. College education pays more attention to students' autonomous learning ability and the cultivation of comprehensive quality and so on. Curriculum and student management tend to be more liberalization. Facing the study pressure is reduced, more and more students begin to relax and ignore the learning, especially for English learning. However, English as a foreign language subject is easy to be forgotten. In college English education is to improve the interest and guide students independent learning and it has higher requirements. To a large extent, the use of project teaching method is to solve this problem. From preparation of implementation of the project, students are to complete the project alone and be driven out of the sense of responsibility and a sense of personal fulfillment will stimulate students' interest in learning to a great extent.

\subsection{Strengthening the students' listening and speaking skills}

Audio-visual education has always been the key and difficult point for English teaching. For college students in China, in response to a written test including speaking, reading and writing ability, spoken English, listening and speaking skills need to be improved.[1] But the traditional teaching mode pays attention to the teacher, they only interprets knowledge and do not strengthen the students practical application abilities in the classroom teaching practice. This leads to the fact that the level of the students' listening and speaking abilities stands still. English is used as a language and you need to understand that this language is widely used in daily life and you should truly learn it flexibly. In the process of the implementation of the project teaching, the teacher teaches assign students some project in accordance with the requirements of project designed for all kinds of situation. In this process, students think fully the project divergently and they combine the textbook content and personal understanding together effectively. In addition, the students also fully exercise the ability to listen and integrated use of English, and they have the very big promotion in the overall language abilities.

\subsection{Cultivating students' creativity}

The purpose of learning is not pay attention to who wins or who loses, but to cultivate everyone involved in the learning process to have creative practice and to enhance their creativity unceasingly. Project teaching method is the process in which the students change from understanding nothing to understand all, starting from zero to the learning process of the completion of the project. In this process, the most important thing is the design of the project and this will determine the specific implementation of the entire project. It also requires that students can have fully divergent thinking on the basis of the textbook knowledge and have creativity to develop a project plan. At the same time, students not only learn knowledge and skills in the process of information gathering, but also experience the hardships and happiness of innovation in the project design. And the result of the project is to fully exercise the student's imagination and cultivate the creativity.

\subsection{Improving students' ability to analyze and solve problems}

One of the biggest characteristics of project teaching method is to take the student as the main body and the whole process is performed independently by the students, teachers only gave proper guidance to students. The aim is to improve students' learning enthusiasm, make them actively involved in the project completion. [3] So in the design of the project implementation, the students can become more independent in the analyzing problems and solving the problem. In traditional English teaching, the teacher is the main body who teaches content to students such as pronunciation, grammar knowledge and skills to solve the problem. But this is only applicable to cope with the examination and it is not effective for the improvement of the students' English practical ability. The project teaching in improving students' ability is applied at the same time and it is more conducive to the students when they have a problem that can be settled independently and they can analyze the problem on their own instead of asking the teacher, that is the old model. Eventually it will make the students absorb knowledge deeply and meticulously to a great extent.

\subsection{Developing the students' ability of organization; coordination and unity cooperation}

The most typical project teaching method is to develop the project team through group discussion and divide the class into several teams to complete the project tasks. Due to the differences of personality traits of team members and the 
differences of project implementation idea, it will result in the disagreement among the team members in the process of the completion of the project, so this is a great challenge to the project. The key is good organization and coordination of each person's point of views and the best solution is to seek common ground and put aside differences. The distribution of the task should be based on different personal strengths at the same time. Team collaboration is significant to project task. Therefore, the implementation of the project teaching method is to cultivate students' ability of organization and coordination and team coordination. [5] Actual operation makes the student feel like a real situation, which in some extent, to inspire the students' work in the future.

\section{PRACTICAL APPLICATION OF PROJECT TEACHING METHOD IN COLLEGE ENGLISH TEACHING}

In recent years, with the deepening reform of education system, the project teaching method as a new education mode is gradually introduced in colleges and universities and is widely used. In college English teaching, the implementation of the project type teaching fully mobilize the students subjective initiative and potential ability in learning English, to fundamentally solve the common problems existing in current college English teaching. This article from the following several aspects of the application of project teaching method in college English teaching are analyzed.

\subsection{Of project planning, fully arouse the enthusiasm of students' participation in the project}

Project teaching method as a new method of teaching has high requirements for students and teachers and the interaction between students and students, it needs the teachers and students to work together to complete one or more tasks of the project. Therefore, before the curriculum, teacher must develop detailed plans in view of the teaching content to conform to the requirements, and design a variety of ways and improve the interest of the project in order to stimulate students to participate in the project with positive initiative. In English teaching, the traditional model is too dull and boring. Teachers can understand students by means of investigating their interest or orientation. Teachers should make a survey of the understanding of project teaching and teaching mode of project expectations and opinions.[4] For example, with the method of questionnaire to let the students give their ideas.

\subsection{According to the teaching requirements and needs of the course content, select the appropriate project tasks}

College English teaching content is large and wide and practical; , so teachers should design the course content according to the overall level of the students and to fully cover the teaching mission of project tasks. In the beginning of the course teachers should set up the project teams and start to select the project leaders, and according to the project task allocation order, team members should take on the task of a project planner in turn to ensure the smooth completion of the project. In the practice of teaching, the teacher can assign the projects according to the units of the content and let each team to show their project in front of the class and implement the evaluation of the project.

\section{(1) The term overall project schedule}

The overall project allocation is at the beginning of the semester, the teacher work out a plan for feasible project tasks according to the syllabus for this semester curriculum arrangement, clear learning goals and steps of the semester. And students formed their teams freely under the guidance of the teacher; members identify project tasks and task assignments. In <the New Horizon College English >the first book, for example, curriculum has eight units, each unit has a theme, theme and content are closely related to student life, it is more conducive to the project teaching. The students can play the role of the teachers, for example, the team can make their PowerPoint on their own and teach other students. The teacher can assign units to different teams, let students be the teachers and complete the whole teaching of the course content. The implementation of the project tasks not only can let the students know more knowledge but also can stimulate students' enthusiasm for English learning, even largely improve students' English speaking ability and performance.

(2) The unit project tasks arrangement

After the whole project tasks to develop students into the independent design creation process, they can take the initiative to consult materials and get involved in the content of the project. But because of some students' poor self-control, they failed to give full play to the role in the team project. This requires teachers to design a specific project tasks in unit in order to promote the students to fully participate in the college English learning. For example, in <the New Horizon College English $>$ the first book of the first unit of teaching process, the teacher can organize the game of role play, played by members of the team; creating a new environment by using the learned words, grammar and sentences in the text. Teachers should encourage students to prepare the 
task ahead of time and think independently, so they can make full use of what they learned.

(3) The project assignment before class and after class

Restricted by class time, teachers need to let students learn more knowledge in a very short period of time, and the projects can be carried out after class. Teachers can assign students to dialogue or articles after class and let them carry on the creation and performance. The content before and after the class distribution is more targeted, it can effectively help the students to absorb to master teaching contents. At the same time, in order to arouse the enthusiasm of the introverted students, it can effectively improve thinking ability and oral English and listening ability in the process of speech or performance. At this time the project allocation is forced. It is required that every student should complete the task with good quality, therefore it is a big push for students' daily learning.

\subsection{With the method of project achievements examination to assess student's final grade}

In college education, student achievement evaluation is not only on the basis of test scores; more important is the appraisal of students' overall performance and comprehensive quality. And evaluation of project results can reflect the learning situation of students throughout the semester fundamentally and more fully, it is helpful for the teacher and students to make more intuitive assessments of their achievements. In the project achievements inspection, the first step is to let project team members inspect their project on their own. Second, according to the requirements of the project course, evaluation is performed by the teachers. The teacher should find existing problems and requires correction. At the same time, the group can communicate with each other, and puts forward opinions, reflect continuously changes. Eventually, the teacher makes the final evaluation on the basis of the course content. In the same time, it is necessary to pay attention to college English test band 4 and band 6 .

\section{THE CONCLUSION}

The application of project teaching method in college English teaching, is by giving students decorate project tasks, drive students to think actively and explore, and it can change passive learning into active learning. In the process of implementation, the design of the project is helpful to cultivate students' ability to analyze and solve problems, to let the students thinking more clearly; The diversity of the content of the project and life is good for improving the students' participation and nationality. Many members of the project implementation is beneficial to strengthen students' team cooperation ability. Project in the contextualized form can benefit students to have indepth understanding of knowledge, and develop the social skills. Project evaluation is beneficial to active classroom atmosphere, and it can arouse the enthusiasm of students, at the same time the students find a pleasant environment and correct their own mistakes. The implementation of the project teaching method makes the teacher's own business level into a higher request; it also improve student's comprehensive. Through elaborate design of the project, students will learn the content deeply and constantly improve the level of English from all aspects including listening, speaking, reading and writing. This method is significant for college students to train the practical application of English ability.

\section{REFERENCES}

[1] Dong Li. Project 2009 Teaching Method in College English Listening and Speaking Class in Practice Research. China Electric Power, Education (11): 203-204.

[2] Jiang Dayuan. 2007 Vocational Pedagogy Research New. Beijing: Education Science Press.

[3] Shan Bufen. 2009 Higher Vocational English Project Teaching Method of Application and Limitations. Science Wenhui (12): 167188.

[4] Shao Dan. 2006 College English Classroom Interactive Teaching Model to Explore. Journal of Anhui Literature 11.

[5] Zhao Jinchuan, Wu Heping, Wan Ying. 2009 English Writing Project Teaching Method to Explore the Practice. Journal of Success: Education (7): 11-12. 